
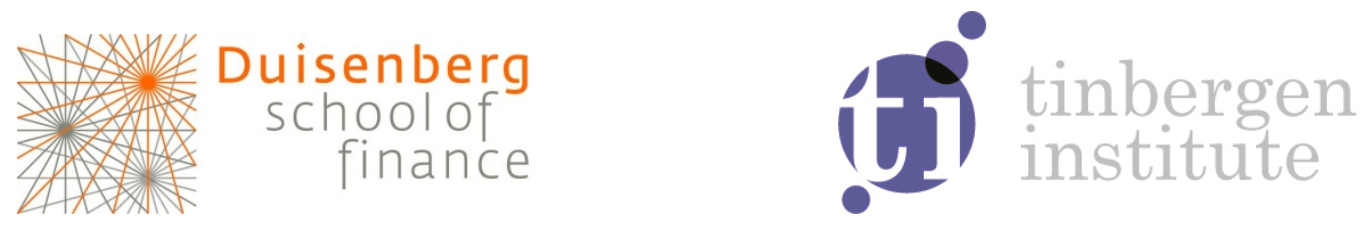

Duisenberg school of finance - Tinbergen Institute Discussion Paper

TI 13-052 / VI /DSF 55

\title{
Long-Term Government Debt, Financial Fragility and Sovereign Default Risk
}

Christiaan van der Kwaak

Sweder van Wijnbergen 
Tinbergen Institute is the graduate school and research institute in economics of Erasmus University Rotterdam, the University of Amsterdam and VU University Amsterdam.

More TI discussion papers can be downloaded at http://www.tinbergen.nl

Tinbergen Institute has two locations:

Tinbergen Institute Amsterdam

Gustav Mahlerplein 117

1082 MS Amsterdam

The Netherlands

Tel.: +31(0)205251600

Tinbergen Institute Rotterdam

Burg. Oudlaan 50

3062 PA Rotterdam

The Netherlands

Tel.: +31(0)10 4088900

Fax: +31(0)104089031

Duisenberg school of finance is a collaboration of the Dutch financial sector and universities, with the ambition to support innovative research and offer top quality academic education in core areas of finance.

DSF research papers can be downloaded at: http://www.dsf.nl/

Duisenberg school of finance

Gustav Mahlerplein 117

1082 MS Amsterdam

The Netherlands

Tel.: +31(0)20 5258579 


\title{
Long Term Government Debt, Financial Fragility and Sovereign Default Risk
}

\author{
Christiaan van der Kwaak and Sweder van Wijnbergen ${ }^{1}$ \\ Tinbergen Institute and Department of Economics, University of Amsterdam
}

March 2013

\begin{abstract}
We analyze the interaction between bank rescues, financial fragility and sovereign debt discounts. To that end we set up a model that contains balance sheet constrained financial intermediaries financing both capital expenditure of intermediate goods producers and government deficits. The financial intermediaries face the risk of a (partial) default of the government on its debt obligations due to the fact that there exists a maximum level of debt service that is politically feasible ("Fiscal Limit"). First we analyze the impact of a financial crisis, comparing the case of full credibility of government debt with the case of an endogenous sovereign debt discount. We find that the introduction of the default possibility does not in itself have an effect on the equilibrium outcome under the assumption of short term debt finance only. Interest rates on debt reflect higher default probabilities, but because all debt is short term, bank balance sheets are unaffected and no further negative amplification effects arise through the endogenous sovereign debt channel. This changes when long term government debt is introduced due to the impact of capital losses on bank balance sheets. We find that the equilibrium outcome significantly deteriorates with respect to the case where the government uses short term debt. Higher interest rates on new debt lead to capital losses on banks' holding of existing long term government debt. The associated increase in credit tightness leads to a strongly negative amplification effect, significantly increasing the output losses, recession duration and declines in investment after a financial crisis. This raises potential conflicting macroeconomic influences of a debt financed recapitalization of banks after a financial crisis. We investigate the case where the government tackles the financial crisis by announcing a recapitalization of the financial system to occur 4 quarters after announcement. Under the parameter values chosen, the positive effects from an anticipated capital injection dominate the effects of the associated increase in sovereign default risk.
\end{abstract}

Keywords: 'Financial Intermediation; Macrofinancial Fragility; Fiscal Policy; Sovereign Default Risk'

JEL classification: E44; E62; H30

\footnotetext{
${ }^{1}$ Contact details: University of Amsterdam, Valckenierstraat 65-67, 1018 XE Amsterdam, the Netherlands; e-mail address: s.j.g.vanwijnbergen@uva.nl
} 


\section{Introduction}

The current eurozone crisis has fully exposed the important link between the financial system and government financing. The immediate response by governments in advanced economies after the start of the US sub-prime crisis was to save the financial system through deficit financed recapitalization and other forms of financial sector aid Lane (2012). At the same time, these governments engaged in further deficit financed stimulus spending, in order to boost economic activity. The result has been a rapid increase in debt-GDP ratios, causing credit spreads on sovereign bonds to rise sharply in the European periphery.

The crisis clearly marks the contrast between the eurozone on the one hand, and the US on the other hand, where sovereign default risks are of no concern (at least at the moment of writing....). This has at least partially to do with the differences in the financial architecture between the eurozone, where financing occurs mostly through the banking system, and the US, where companies rely more on the capital market for financing. This has led to a large fraction of European sovereign debt being held on the balance sheet of the banking system.

The deficit financed stimulus measures in the middle of an economic downturn made investors aware of the sovereign default risks of Southern European government bonds. Investors started requiring default premia, which lowered bond prices and raised yields accordingly. This risks setting off vicious debt cycles, because the higher interest rate payments increased budget deficits. A second mechanism also runs through the fall in bond prices, to the extent that these bonds were held by commercial banks. The fall in price of government bonds decreased the valuation of these assets on the balance sheet of the financial intermediaries and lowered their net worth. This in turn caused the intermediaries to increase credit spreads and interest rates on loans to the private sector, making non-financial companies less profitable, and leading them to decrease investment. The higher interest rates on government debt forced countries to cut government spending and increase tax rates in order to cut deficits. Together with a drop in investment, this started a recession in the European periphery countries, which further increased sovereign default risks, as can be seen from the spreads on credit default swaps on sovereign bonds. Hence a feedback from financial intermediaries to sovereign states occurred because of the connection through sovereign bonds.

In order to capture the above described dynamics, we build a general equilibrium model that incorporates balance sheet constrained financial intermediaries that supply loans to intermediate goods producers, which use the proceeds to purchase capital that is needed for production. The intermediate goods producers sell their products to the retail goods producers which produce a unique product, and are therefore capable of charging a markup. We introduce price stickiness among the retail goods producers in order to obtain more realistic output dynamics. Besides private sector loans, financial intermediaries also provide financing to the government. Capital producers purchase old capital that has been used by the intermediate goods producers, and they purchase final goods in order to build new capital, which they sell to the intermediate goods producers. The government also purchases final goods, raises taxes, issues debt, and has the possibility of recapitalizing the financial intermediaries.

The innovation of the current paper is the fact that it combines an economy with financial intermediaries that are balance sheet constrained with government bonds subject to sovereign default risk. Since the financial intermediaries hold (a fraction of) public debt on their balance sheet, they are exposed to sovereign risk. Through this channel we capture the interconnectedness between the financial system and the fiscal problems of the government, a link that is at the forefront of 
the current eurozone crisis. We highlight the importance of the maturity structure of the public debt. We first analyse the case of short term debt only where sovereign debt is repaid, and new debt issued, every period. We compare this structure with the other extreme, the case where the government issues perpetual bonds, or 'consols' which only pay a fixed (real) amount in perpetuity. The principal does not have to be repaid by the government, unless it wants to retire the bond, in which case the government buys the bond back against the prevailing market price.

We use consols for analytical convenience, although sovereign consols are currently not issued anymore; but it does allow us to capture the possibility of sovereign risk related capital losses on long term sovereign debt held on banks' balance sheets. Sovereign default risk is captured by the fact that there is a so called maximum level of debt that is politically feasible. We assume that the government follows a core tax policy that guarantees intertemporal solvency in the no default setup. We can compute the level of debt that needs to be issued in order to finance all government obligations, and compare this with the maximum level of debt that is still politically feasible. If the so-called level of no default debt is smaller than the maximum level of debt, the government honors its obligations and does not default, while a default occurs when the level of no default debt is larger than the maximum level of debt that is politically feasible.

We first use the model to assess the effect of introducing sovereign default risk when the government is financed through short term debt. In particular, we want to investigate whether and how financial sector bailout programs affect sovereign default risk, and whether sovereign default risk can feed back to the financial sector, thereby possibly creating an amplification mechanism exacerbating the initial impact of a financial shock. We then analyze the same question but now in the presence of long term government debt that is subject to sovereign default risk. The difference arises from capital losses due to increases in sovereign default premia. New investors can price the higher default risk into the purchase price, but old investors will have to take a capital loss. Finally we will investigate the effect of a recapitalization of the financial sector that is announced when the financial crisis hits, but is only implemented four quarters later. This will allow us to separate between the effects of the recapitalization itself on the one hand, and the anticipation effect on the other hand, due to the forward looking nature of the model.

Since the start of the credit crisis, the theoretical literature with general equilibrium models containing financial frictions is growing. The first paper to incorporate financial frictions in a general equilibrium setup is Bernanke et al. (1999). Gertler and Karadi (2011) introduce financial intermediaries that are balance sheet constrained by an agency problem between the deposit holders and the bank owners. This gives rise to an endogeneous leverage constraint, which becomes more binding when net worth is reduced by for example a negative shock to the quality of the loans. Several others have a similar mechanism, for example Kiyotaki and Moore (1997), and Gertler and Kiyotaki (2010).

An extension of this model that includes financial intermediaries that finance short term government debt besides loans to the private sector is found in Kirchner and Van Wijnbergen (2012). The current paper applies the same model and extends the model by introducing sovereign default risk. Gertler and Karadi (2012) also extend the number of assets held by financial intermediaries by letting them hold a long term government bond in the form of a perpetuity that is very similar to the long term government bond that is used in this paper. The introduction of government bonds financed by financial intermediaries creates a second amplification mechanism, whereby increased government bond issuance, in order to stimulate the economy, can crowd out financing of the private sector. These papers, however, do not take into account the possibility of a government default. Acharya et al. (2011) have a setup containing both financial sector bailouts and sovereign default 
risk, but their analysis occurs within a partial equilibrium setup.

Staggered price setting and price stickiness can be found in Calvo (1983) and Yun (1996). Sovereign default risk is captured in Arellano (2008), which contains an endogeneous default mechanism. She finds a maximum level of debt conditional on the income shock. Uribe (2006) contains a government that defaults on part of its government debt each period in such a way that the expected future tax receipts and liabilities match afterwards. Schabert and Van Wijnbergen (2011) introduce sovereign default risk by assuming that there exists a maximum level of taxation that is politically feasible and stochastic. Investors do not know this maximum level ex-ante, but they do know the distribution, and can deduce that the risk of a default is increasing with government debt. Their way of introducing sovereign risk is similar to the set up used in this paper.

\section{Model description}

The model builds on Kirchner and Van Wijnbergen (2012), and extends their model by including a government that can default. The government issues debt to financial intermediaries and raises taxes in a lump sum fashion from the households to finance its expenditures and repay existing debt. The default probability is increasing in the real debt burden. The other part of the public sector is a central bank that is in charge of monetary policy. It sets the nominal interest rate on the deposits that the households bring to the financial intermediaries. The private sector consists of financial intermediaries and a non-financial sector that includes households and firms. The non financial sector consists of capital producing firms that buy investment goods and used capital, and convert these into capital that is sold to the intermediate goods producers. The intermediate goods producers use the capital as an input, together with labor, to produce intermediate goods for the retail firms. There is perfect competition in the intermediate goods market, and hence the profits of the intermediate goods producers are zero in equilibrium. Each intermediate goods producer produces a differentiated product. The retail firms repackage and sell the retail products to the final goods producer. Every retail firm is a monopolist and charges a markup for his product. The final goods producers buy these goods and combine them into a single output good. The final good is purchased by the households for consumption, by the capital producers to convert it into capital, and by the government. The household maximizes life-time utility subject to a budget constraint, which contains income from deposits, profits from the firms, both financial and non-financial, and from labor. The income is used for consumption, lump sum taxes and investments in deposits.

The financial sector set up builds on Gertler and Karadi (2011) and Kirchner and Van Wijnbergen (2012). Bankers running the financial intermediaries can steal a certain fraction of the assets. If that happens depositors will force the intermediary into bankruptcy, but they can not recoup all the assets stolen by the banker. Depositors, therefore, will in equilibrium only provide deposits up till the level where the continuation value of the intermediaries is equal to the value of the assets that can be diverted by the bankers. This imposes an endogeneous leverage constraint on the financial intermediaries. The funds obtained from the depositors, together with the net worth of the intermediary, are used to provide loans to the intermediate goods producers and to purchase government bonds. The intermediate goods firms need the loans in order to buy capital with which they will be productive in the next period. If the capital deteriorates in quality after the loan has been provided, the intermediate goods firms will produce less, and might not be able to fully repay the loan. This causes the balance sheet of the financial intermediary to worsen, and the intermediary will not be able to provide as many loans as the production sector might demand without the leverage constraint. The government has the possibility to intervene by providing 
the financial sector with new net worth. This, however, increases government debt, and therefore sovereign default risk. This might impact the balance sheet of the financial intermediaries further, because they have to finance the recapitalization, and carry more risk on the balance sheet due to the increased uncertainty about the government bonds. This might cause the intermediaries to cut back lending, increase interest rates further, and can therefore be a second amplification mechanism, further deteriorating economic conditions.

\section{$2.1 \quad$ Household}

The household sector is assumed to consist of a continuum of infinitely lived households that exhibit identical preferences and asset endowments. A typical household consists of bankers and workers. Every period, a fraction $f$ of the household members is a banker running a financial intermediary. A fraction $1-f$ of the household members is a worker. At the end of every period, all members of the household pool their resources, and every member of the household has the same consumption pattern. Hence there is perfect insurance within the household, and the representative agent representation is preserved. Every period, the household earns income from the labor of the working members and the profits of the firms, that are being owned by the household. Besides that, the deposits are paid back with interest. The household uses these means to consume and to bring deposits to financial intermediaries, other than the ones owned by the family, in order to prevent self-financing. The household members get utility from consumption and leisure, with habit formation in consumption, in order to capture consumption dynamics, as in Christiano et al. (2005). The households optimize the expected discounted utility:

$\max _{\left\{c_{t+s}, h_{t+s}, d_{t+s}\right\}_{s=0}^{\infty}} E_{t}\left[\sum_{s=0}^{\infty} \beta^{s}\left(\log \left(c_{t+s}-v c_{t-1+s}\right)-\Psi \frac{h_{t+s}^{1+\varphi}}{1+\varphi}\right)\right], \quad \beta \in(0,1), \quad v \in[0,1), \quad \varphi \geq 0$

where $c_{t}$ is consumption per household member, and $h_{t}$ are hours worked by the members of the household that are workers. The utility function is subject to the following budget constraint:

$$
c_{t}+d_{t}+\tau_{t}=w_{t} h_{t}+\left(1+r_{t}^{d}\right) d_{t-1}+\Pi_{t}
$$

The household optimizes with respect to the budget constraint. Intermediary deposits $d_{t}$ are one period loans bought at time $t-1$ for a price of one, that pay interest $r_{t}^{d}$ and principal at time $t$. $w_{t}$ is the real wage rate, $\tau_{t}$ are the lump sum tax payments the household has to pay to the government, and $\Pi_{t}$ are the profits from the firms that are owned by the households. The profits of the financial intermediary are net of the startup capital for new bankers, as will be explained below. The first order conditions are now given by:

$$
\begin{aligned}
c_{t}: & \lambda_{t}=\left(c_{t}-v c_{t-1}\right)^{-1}-v \beta E_{t}\left[\left(c_{t+1}-v c_{t}\right)^{-1}\right] \\
h_{t} & : \Psi h_{t}^{\varphi}=\lambda_{t} w_{t} \\
d_{t} & : \quad 1=\beta E_{t}\left[\Lambda_{t, t+1}\left(1+r_{t+1}^{d}\right)\right]
\end{aligned}
$$

where $\lambda_{t}$ is the Lagrange multiplier of the budget constraint, and $\Lambda_{t, t+i}=\lambda_{t+i} / \lambda_{t}$ for $i \geq 0$. The budget constraint is binding when the multiplier is larger than zero, i.e. $\lambda_{t}>0$. 


\section{$2.2 \quad$ Financial intermediaries}

The financial sector is setup similar to Gertler and Kiyotaki (2010). Our model is an extension in the sense that we allow the financial intermediary the choice between investing in private loans and government bonds, like in Kirchner and Van Wijnbergen (2012) and Gertler and Karadi (2012). Financial intermediaries lend funds obtained from households to the intermediate goods producers. We assume that the households do not bring their deposits to the bankers belonging to the household, in order to prevent self-financing. Since we have a continuum of households with mass one, there are many other banks to which the household can lend its funds. The banker's intermediate period balance sheet is given by:

$$
p_{j, t}=n_{j, t}+d_{j, t}
$$

where $p_{j, t}$ are the assets on the balance sheet of bank $j$ in period $t, n_{j, t}$ denotes the net worth of the bank, while $d_{j, t}$ denotes the deposits of the bank. The financial intermediary invests the funds obtained from the household in claims issued by the intermediate goods producer, and government bonds. Hence the asset side of the bank's balance sheet has the following structure:

$$
p_{j, t}=q_{t}^{k} s_{j, t}^{k}+s_{j, t}^{b}
$$

where $s_{j, t}^{k}$ are the number of claims the financial intermediary $j$ has acquired from the intermediate goods producers that pay a net real return $r_{t+1}^{k}$ at the beginning of period $t+1$ for a price $q_{t}^{k}$, and $s_{j, t}^{b}$ the number of government bonds acquired by intermediary $j$, for a net real return $r_{t+1}^{b}$ at the beginning of period $t+1$. Financial intermediaries earn a return on their assets, and pay a return on the deposits. The difference between the two is equal to the increase in the net worth from one period to the next. The government, though, can decide to default on its debt, in which case the financial intermediary only gets $1-\Delta_{t+1}$ from the amount it is supposed to be paid by the government. The balance sheet of intermediary $j$ then evolves according to the following law of motion:

$$
\begin{aligned}
n_{j, t+1} & =\left(1+r_{t+1}^{k}\right) q_{t}^{k} s_{j, t}^{k}+\left(1+r_{t+1}^{b}\right)\left(1-\Delta_{t+1}\right) s_{j, t}^{b}-\left(1+r_{t+1}^{d}\right) d_{j, t}+n_{j, t+1}^{g}-\tilde{n}_{j, t+1}^{g} \\
& =\left(r_{t+1}^{k}-r_{t+1}^{d}\right) q_{t}^{k} s_{j, t}^{k}+\left(r_{t+1}^{b}\left\{1-\Delta_{t+1}\right\}-r_{t+1}^{d}\right) s_{j, t}^{b}+\left(1+r_{t+1}^{d}\right) n_{j, t}+\tau_{t+1}^{n} n_{j, t}-\tilde{\tau}_{t+1}^{n} n_{j, t}
\end{aligned}
$$

where $n_{j, t+1}^{g}=\tau_{t+1}^{n} n_{j, t}$ denotes the net worth provided by the government to the financial intermediary $j$, while $\tilde{n}_{j, t+1}^{g}=\tilde{\tau}_{t+1}^{n} n_{j, t}$ denotes the repayment of government support received in previous periods. We will describe later how the government can default.

The financial intermediary is interested in maximizing expected profits. There is a probability of $1-\theta$ that the banker has to exit the industry next period, in which case he will bring the net worth $n_{j, t+1}$ to the household, while he is allowed to continue operating with a probability $\theta$. The banker discounts these outcomes by the stochastic discount factor $\beta \Lambda_{t, t+1}$ The banker's objective is then given by the following Bellman equation:

$$
V_{j, t}=\max E_{t}\left[\beta \Lambda_{t, t+1}\left\{(1-\theta) n_{j, t+1}+\theta V_{j, t+1}\right\}\right]
$$

where $\Lambda_{t, t+1}=\lambda_{t+1} / \lambda_{t}$. We conjecture the solution to be of the following form, and later check whether this is the case:

$$
V_{j, t}=\nu_{t}^{k} q_{t}^{k} s_{j, t}^{k}+\nu_{t}^{b} s_{j, t}^{b}+\eta_{t} n_{j, t}
$$


We assume the banker can divert a fraction $\lambda$ of the assets at the beginning of the period, and transfer these assets costlessly back to the household. The depositors will force the intermediary into bankruptcy, but will only be able to recover the remaining fraction $1-\lambda$ of the assets of the financial intermediary, since we assume that it is too costly for them to recoup all the assets. Hence lenders will only supply funds if the gains from stealing are lower than the continuation value of the financial intermediary. This gives rise to the following constraint:

$$
V_{j, t} \geq \lambda\left(q_{t}^{k} s_{j, t}^{k}+s_{j, t}^{b}\right) \quad \Rightarrow \quad \nu_{t}^{k} q_{t}^{k} s_{j, t}^{k}+\nu_{t}^{b} s_{j, t}^{b}+\eta_{t} n_{j, t} \geq \lambda\left(q_{t}^{k} s_{j, t}^{k}+s_{j, t}^{b}\right)
$$

where $\phi_{t}$ denotes the ratio of assets to net worth, which can be seen as the leverage constraint of the financial intermediary. The optimization problem can now be formulated in the following way:

$$
\max _{\left\{q_{t}^{k} s_{j, t}^{k}, s_{j, t}^{b}\right\}} V_{j, t}, \quad \text { s.t. } \quad V_{j, t} \geq \lambda\left(q_{t}^{k} s_{j, t}^{k}+s_{j, t}^{b}\right)
$$

From the first order conditions we find that $\nu_{t}^{b}=\nu_{t}^{k}$. Hence the leverage constraint (4) can be rewritten in the following way:

$$
\nu_{t}^{k}\left(q_{t}^{k} s_{j, t}^{k}+s_{j, t}^{b}\right)+\eta_{t} n_{j, t} \geq \lambda\left(q_{t}^{k} s_{j, t}^{k}+s_{j, t}^{b}\right) \Rightarrow q_{t}^{k} s_{j, t}^{k}+s_{j, t}^{b} \leq \phi_{t} n_{j, t}, \quad \phi_{t}=\frac{\eta_{t}}{\lambda-\nu_{t}^{k}}
$$

Substitution of the conjectured solution into the right hand side of the Bellman equation gives the following expression for the continuation value of the financial intermediary:

$$
\begin{aligned}
V_{j, t} & =E_{t}\left[\Omega_{t+1} n_{j, t+1}\right], \\
\Omega_{t+1} & =\beta \Lambda_{t, t+1}\left\{(1-\theta)+\theta\left[\eta_{t+1}+\nu_{t+1}^{k} \phi_{t+1}\right]\right\}
\end{aligned}
$$

$\Omega_{t+1}$ can be thought of as a stochastic discount factor that incorporates the financial friction. Now we can substitute the expression for next period's net worth into the expression above:

$$
\begin{aligned}
V_{j, t} & =E_{t}\left[\Omega_{t+1} n_{j, t+1}\right]=E_{t}\left[\Omega_{t+1}\left\{R_{t+1}^{k} q_{t}^{k} s_{j, t}^{k}+R_{t+1}^{b}\left(1-\Delta_{t+1}\right) s_{j, t}^{b}-R_{t+1} d_{j, t}+n_{j, t+1}^{g}-\tilde{n}_{j, t+1}^{g}\right\}\right] \\
& =E_{t}\left[\Omega_{t+1}\left\{\left(R_{t+1}^{k}-R_{t+1}\right) q_{t}^{k} s_{j, t}^{k}+\left(R_{t+1}^{b}\left(1-\Delta_{t+1}\right)-R_{t+1}\right) s_{j, t}^{b}+\left(R_{t+1}+\tau_{t+1}^{n}-\tilde{\tau}_{t+1}^{n}\right) n_{j, t}\right\}\right]
\end{aligned}
$$

After combining the conjectured solution with (??), we find the following first order conditions:

$$
\begin{aligned}
\eta_{t} & =E_{t}\left[\Omega_{t+1}\left(1+r_{t+1}^{d}+\tau_{t+1}^{n}-\tilde{\tau}_{t+1}^{n}\right)\right] \\
\nu_{t}^{k} & =E_{t}\left[\Omega_{t+1}\left(r_{t+1}^{k}-r_{t+1}^{d}\right)\right] \\
\nu_{t}^{b} & =\nu_{t}^{k}=E_{t}\left[\Omega_{t+1}\left(\left(1+r_{t+1}^{b}\right)\left(1-\Delta_{t+1}\right)-\left(1+r_{t+1}^{d}\right)\right)\right] \\
\Omega_{t+1} & =\beta \Lambda_{t, t+1}\left\{(1-\theta)+\theta\left[\eta_{t+1}+\nu_{t+1}^{k} \phi_{t+1}\right]\right\}
\end{aligned}
$$

\subsubsection{Financial sector support}

Individual financial intermediaries are forward-looking, and hence incorporate financial sector support when forming expectations about their future net worth. We assume that the support provided 
to an individual intermediary is proportional to the intermediary's net worth in the previous period, in order to relate the support to the pre-crisis level of net worth. Hence individual financial support is given by:

$$
\begin{aligned}
n_{j, g, t} & =\tau_{t}^{n} n_{j, t-1}, \quad \zeta \leq 0, \quad l \geq 0 \\
\tau_{t}^{n} & =\zeta\left(\xi_{t-l}-\xi\right)
\end{aligned}
$$

When the financial sector support has to be paid back, some of the firms that have received the support will have gone out of business. Therefore the government levies a tax on the previous period net worth of the financial intermediaries in order to get paid back the full amount of support measures, which have to be paid by all previous period intermediaries, including the ones exiting:

$$
\tilde{n}_{j, g, t}=\tilde{\tau}_{t}^{n} n_{j, t-1}
$$

where $\tilde{\tau}_{t}^{n}$ is a scaling factor that changes over time as well.

\subsubsection{Aggregation of financial variables}

We can integrate over the balance sheets of the financial intermediaries to obtain the aggregate balance sheet of the financial sector:

$$
p_{t}=n_{t}+d_{t}
$$

Aggregation over the asset side of the balance sheet gives the composition of the aggregated financial system:

$$
p_{t}=q_{t}^{k} s_{t}^{k}+s_{t}^{b}
$$

Since $\phi_{t}$ does not depend on firm specific factors, we can aggregate the leverage constraint (5) across financial intermediaries to find the total number of assets:

$$
p_{t}=q_{t}^{k} s_{t}^{k}+s_{t}^{b}=\phi_{t} n_{t}
$$

where $p_{t}$ denotes the aggregate quantity of assets that are on the balance sheets of the financial intermediaries, while $n_{t}$ denotes the aggregate intermediary net worth. We see that the gross return on the assets will be below the return on deposits if the capital $k_{t}$ is hit with a quality shock between the moment the intermediary lends the funds to the goods producer and the production of the goods. This will cause the intermediary's capital to decline, which s him to deleverage in order not to violate the leverage constraint. The share of assets invested in private loans is given by:

$$
\omega_{t}=q_{t}^{k} s_{t}^{k} / p_{t}
$$

At the same time, we know that at the end of the period, only a fraction $\theta$ of the current bankers will remain a banker, while the remaining fraction $1-\theta$ will become a worker. We assume that the current bankers only pay out dividends at the moment they quit the banking business. If they do not quit, they retain their net worth, in order to be able to expand their balance sheet and make a larger profit. We know then that the net worth of the existing bankers at the end of the period is equal to:

$$
n_{e, t}=\theta\left[\left(r_{t}^{k}-r_{t}^{d}\right) q_{t-1}^{k} s_{t-1}^{k}+\left(\left(1-\Delta_{t}\right)\left(1+r_{t}^{b}\right)-\left(1+r_{t}^{d}\right)\right) s_{t-1}^{b}+\left(1+r_{t}^{d}\right) n_{t-1}\right]
$$


At the same time, the exiting bankers bring back the net worth to the household income. We know that a fraction $1-\theta$ of the bankers has left the financial industry, which is equal to a fraction $(1-\theta) f$ of the household. We know that the same fraction of the household will enter the financial industry next period by leaving their working job. We assume that the household will provide a starting net worth to the new bankers proportional to the assets of the old bankers, as in Gertler Karadi (2011). Now we assume that the household transfers a fraction of $\chi /(1-\theta)$ of the assets of the old bankers to the new bankers. Hence the aggregate net worth of the new bankers will be equal to:

$$
n_{n, t}=\chi p_{t-1}
$$

Then the total net worth at the beginning of the new period, after the default decision has been made, and it has been decided which bankers will leave the industry, will be given by:

$$
\begin{aligned}
n_{t} & =n_{e, t}+n_{n, t} \\
& =\theta\left[\left(r_{t}^{k}-r_{t}^{d}\right) q_{t-1}^{k} s_{t-1}^{k}+\left(\left(1-\Delta_{t}\right)\left(1+r_{t}^{b}\right)-\left(1+r_{t}^{d}\right)\right) s_{t-1}^{b}+\left(1+r_{t}^{d}\right) n_{t-1}\right] \\
& +\chi p_{t-1}+n_{t}^{g}-\tilde{n}_{t}^{g}
\end{aligned}
$$

where $n_{t}^{g}$ and $\tilde{n}_{t}^{g}$ are aggregate financial sector support, respectively financial support payback. Since individual support is proportionalto the individual intermediary's net worth, it is straightforward to get aggregate financial sector support:

$$
n_{t}^{g}=\zeta\left(\xi_{t-l}-\xi\right) n_{t-1}
$$

Similarly, we can aggregate financial sector payback:

$$
\tilde{n}_{t}^{g}=\tilde{\tau}_{t}^{n} n_{t-1} \Rightarrow \tilde{\tau}_{t}^{n}=\tilde{n}_{g, t} / n_{t-1}
$$

we derive the expression for $\tilde{n}_{g, t}$ below, in section 2.4 .

\subsection{Production side}

The production side of the economy will be modeled in the same way as in Kirchner and Van Wijnbergen (2012). We have a continuum of intermediate goods producers indexed by $i \in[0,1]$ that face perfect competition. They have to borrow funds from the financial intermediary in order to be able to purchase the capital necessary for production. With the proceeds from the sale of the output and the sale of the capital after it has been used, the firms will pay workers and pay back the loans to the financial intermediary. The output is sold to the retail firms. The capital producers buy the capital that has been used, and transform the used capital, together with the investments purchased from the final goods producers, into new capital. This new capital is sold to the intermediate goods producers, which will use it for production next period. A continuum of retail firms, indexed by $f \in[0,1]$, repackage the products bought from the intermediate goods producers to produce a unique differentiated retail product. The retail firms sell their products to a continuum of final goods producers. Due to the fact that the products are differentiated, each individual retail firm faces a monopolistic competitive market, and can charge a markup. It can only change prices in a period, though, with a certain probability, which is equal to $\psi$ and i.i.d. for every retail firm. Hence some firms are allowed to reset prices while others are not. The final goods producers have a technology to convert the inputs from the retail firms into final goods. Due 
to perfect competition, the profits will be zero in equilibrium, and the final goods are sold to the households, the government, and the capital producers, which use it as an investment to produce new capital for use in the next period by the intermediate goods producing firms.

\subsubsection{Capital Producers}

In this section we describe the capital producers. At the end of period $t$, when the intermediate goods firms have produced, the capital producers buy the remaining stock of capital from the intermediate goods producers at a price $q_{t}^{k}$. They combine this capital with investment goods bought from the final goods producers to produce new capital. This capital is being sold to the intermediate goods producers at a price $q_{t}^{k}$. We assume that the capital producers face convex adjustment costs with respect to previous period investment $i_{t-1}$. These adjustment costs are the reason that one unit of investment goods cannot be transformed into one unit of capital, unless $i_{t}=i_{t-1}$. Hence we have the following capital producing technology:

$$
k_{t}=(1-\delta) \xi_{t} k_{t-1}+\left(1-\Psi\left(\iota_{t}\right)\right) i_{t}, \quad \Psi(x)=\frac{\gamma}{2}(x-1)^{2}, \quad \iota_{t}=i_{t} / i_{t-1}
$$

where $i_{t}$ denotes investment goods that are being acquired from the final goods producers for a relative price of unity. The capital producers are profit maximizing, and the profits are passed on to the households, who are the owners of the capital producers. The profit in period $t$ is given by:

$$
\Pi_{t}^{c}=q_{t}^{k} k_{t}-q_{t}^{k}(1-\delta) \xi_{t} k_{t-1}-i_{t}
$$

The capital producers' optimization problem is then given by:

$$
\max _{\left\{i_{t+i}\right\}_{i=0}^{\infty}} E_{t}\left[\sum_{i=0}^{\infty} \beta^{i} \Lambda_{t, t+i}\left(q_{t+i}^{k}\left(1-\Psi\left(\iota_{t+i}\right)\right) i_{t+i}-i_{t+i}\right)\right]
$$

Differentiation with respect to investment gives the first order condition for the capital producers:

$$
q_{t}^{k}\left(1-\Psi\left(\iota_{t}\right)\right)-1-q_{t}^{k} \iota_{t} \Psi^{\prime}\left(\iota_{t}\right)+\beta E_{t} \Lambda_{t, t+1} q_{t+1}^{k} \iota_{t+1} \Psi^{\prime}\left(\iota_{t+1}\right)=0
$$

This equation can be rewritten to find the price of capital to be:

$$
\frac{1}{q_{t}^{k}}=1-\frac{\gamma}{2}\left(\frac{i_{t}}{i_{t-1}}-1\right)^{2}-\frac{\gamma i_{t}}{i_{t-1}}\left(\frac{i_{t}}{i_{t-1}}-1\right)+\beta E_{t}\left[\Lambda_{t, t+1} \frac{q_{t+1}^{k}}{q_{t}^{k}}\left(\frac{i_{t+1}}{i_{t}}\right)^{2} \gamma\left(\frac{i_{t+1}}{i_{t}}-1\right)\right]
$$

\subsubsection{Intermediate Goods Producers}

There exists a continuum of intermediate goods producers indexed by $i \in[0,1]$. Each of these firms produce a differentiated good. The producers are operating in an environment of perfect competition, and hence their profits will be zero in equilibrium. Their production technology is given by:

$$
y_{i, t}=a_{t}\left(\xi_{t} k_{i, t-1}\right)^{\alpha} h_{i, t}^{1-\alpha}, \quad \log \left(x_{t}\right)=\rho_{x} \log \left(x_{t-1}\right)+\varepsilon_{x, t}
$$

where $x_{t}$ can denote total factor productivity $a_{t}$ or capital quality $\xi_{t}$. The innovation $\varepsilon_{x, t}$ is distributed according $\varepsilon_{x, t} \sim N\left(0, \sigma_{x}^{2}\right)$. The intermediate goods producer acquires the capital at the 
end of period $t-1$, while the production only occurs after the capital quality shock $\xi_{t}$ has hit at the beginning of period $t$. Hence $\xi_{t} k_{i, t-1}$ denotes the effective capital in our model. We see that if a negative realization of $\varepsilon_{\xi, t}$ occurs, the quality of the capital deteriorates. Hence the firm will not be able to produce as much as when the shock does not occur. We remember that the number of claims $\left(s_{i, t}^{k}\right)$ is equal to the number of units of capital purchased $\left(k_{i, t}\right)$, and hence the return on the claims of the financial intermediary will be lower. We can think of the shock $\xi_{t}$ as economic depreciation or the obsolescence of the capital. The intermediate goods producer decides at the end of period $t-1$ how much capital to purchase. At the moment the intermediate goods producer purchases the capital, he will not know the realization of $\xi_{t}$ in period $t$ though. Besides that, he needs to issue claims $s_{i, t-1}^{k}$, where the number of claims is equal to the number of units capital $\left(k_{i, t-1}\right)$ acquired. The price of the claims is equal to $q_{t-1}^{k}$, and pay a state-contingent net real return $r_{t}^{k}$ in period $t$. The intermediate goods producer hires labor $h_{i, t}$ for a wage rate $w_{t}$ after the shock $\left(\xi_{t}\right)$ has been realized. When the firm has produced in period $t$, the output is sold for a relative price $m_{t}$ to the retail firms. $m_{t}$ is the relative price of the intermediate goods with respect to the price level of the final goods, i.e. $m_{t}=P_{t}^{m} / P_{t}$. The intermediate goods producing firms sell back the effective capital to the capital producers for a price of $q_{t}^{k}$. The effective capital has depreciated during production, and hence the intermediate goods producer obtains $q_{t}^{k}(1-\delta) \xi_{t} k_{i, t-1}$ for selling the capital. Hence the real profit in period $t$ is given by:

$$
\Pi_{i, t}=m_{t} a_{t}\left(\xi_{t} k_{i, t-1}\right)^{\alpha} h_{i, t}^{1-\alpha}+q_{t}^{k}(1-\delta) \xi_{t} k_{i, t-1}-\left(1+r_{t}^{k}\right) q_{t-1}^{k} k_{i, t-1}-w_{t} h_{i, t}
$$

The objective of the intermediate goods producing firms is to maximize profits. Since the firms are ultimately owned by the household, they apply the same stochastic discount factor as the households $\left(\beta^{s} \Lambda_{t, t+s}\right)$. They take the relative output price $\left(m_{t}\right)$, and the input prices $q_{t}^{k}, r_{t}^{k}$ and $w_{t}$ as given when maximizing profits. The intermediate goods producing firms are therefore faced with the following optimization problem:

$$
\max _{\left\{k_{t+s}, h_{t+s}\right\}_{s=0}^{\infty}} E_{t}\left[\sum_{s=0}^{\infty} \beta^{s} \Lambda_{t, t+s} \Pi_{i, t+s}\right]
$$

The first order conditions belonging to this problem are given by:

$$
\begin{aligned}
k_{i, t}: & E_{t}\left[\beta \Lambda_{t, t+1} q_{t}^{k}\left(1+r_{t+1}^{k}\right)\right]=E_{t}\left[\beta \Lambda_{t, t+1}\left(\alpha m_{t+1} y_{i, t+1} / k_{i, t}+q_{t+1}^{k}(1-\delta) \xi_{t+1}\right)\right] \\
h_{i, t} & : \quad w_{t}=(1-\alpha) m_{t} y_{i, t} / h_{i, t}
\end{aligned}
$$

Since there is perfect competition between the intermediate goods producing firms, the profits will be zero in equilibrium. Therefore the firms will pay out the residual of the revenues back to the financial intermediaries. By substituting the first order condition for the wage rate into the zero-profit condition $\Pi_{i, t}=0$, we can find an expression for the ex-post return on capital:

$$
r_{t}^{k}=\left(q_{t-1}^{k}\right)^{-1}\left(\alpha m_{t} y_{i, t} / k_{i, t-1}+q_{t}^{k}(1-\delta) \xi_{t}\right)-1
$$

Now we rewrite the first order condition for labor and the expression for the ex-post return on capital to find the factor demands. These are given by:

$$
\begin{aligned}
k_{i, t-1} & =\alpha m_{t} y_{i, t} /\left[q_{t-1}^{k}\left(1+r_{t}^{k}\right)-q_{t}^{k}(1-\delta) \xi_{t}\right] \\
h_{i, t} & =(1-\alpha) m_{t} y_{i, t} / w_{t}
\end{aligned}
$$


Now we can find the relative intermediate output price $m_{t}$ by substituting the factor demands into the production technology function:

$$
m_{t}=\alpha^{-\alpha}(1-\alpha)^{\alpha-1} a_{t}^{-1}\left(w_{t}^{1-\alpha}\left[q_{t-1}^{k}\left(1+r_{t}^{k}\right) \xi_{t}^{-1}-q_{t}^{k}(1-\delta)\right]^{\alpha}\right)
$$

\subsubsection{Retail firms}

Retail firms purchase goods $\left(y_{i, t}\right)$ from the intermediate goods producing firms for a nominal price $P_{t}^{m}$, and convert these into retail goods $\left(y_{f, t}\right)$. These goods are sold for a nominal price $P_{f, t}$ to the final goods producer. We assume that it takes one intermediate goods unit to produce one retail good $\left(y_{i, t}=y_{f, t}\right)$. All the retail firms produce a differentiated retail good. The individual retail firm, therefore, operates in a monopolistic competitive market, and can hence charge a markup over the input price $P_{t}^{m}$. Hence the nominal profit for the retail firm is given by $\left(P_{f, t}-P_{t}^{m}\right) y_{f, t}$.

We assume that in each period, one fraction of retail firms is allowed to reset their prices optimally, while the remaining firms are not allowed to do so. This is done in a way similar to Calvo (1983) and Yun (1996). We also assume that this probability is independent of the probability that other producers are allowed to reset their prices, and independent of the previous period decision whether or not the firm was allowed to adjust its prices. Hence the probability that a firm is not allowed to reset its prices is $\psi$, where $\psi$ is i.i.d. Therefore a fraction of $1-\psi$ is allowed to reset their prices, while a fraction $\psi$ is not allowed to reset prices. When a firm is allowed to reset its prices, it will do it in such a way that the expected sum of discounted profits is maximized. Again, the retail firms are owned by the households, and therefore the stochastic discount factor for the nominal pay-outs to the household is given by $\beta^{s} \Lambda_{t, t+s}\left(P_{t} / P_{t+s}\right)$. The relevant part of the optimization problem of the typical retail firm is now given by:

$$
\max _{P_{f, t}} E_{t}\left[\sum_{s=0}^{\infty}(\beta \psi)^{s} \Lambda_{t, t+s}\left(P_{t} / P_{t+s}\right)\left[P_{f, t}-P_{t}^{m}\right]\right] y_{f, t+s}
$$

where $y_{f, t}=\left(P_{f, t} / P_{t}\right)^{-\epsilon} y_{t}$ is the demand function. $y_{t}$ is the output of the final goods producing firms, and $P_{t}$ the general price level. The expression for the demand function for the retail firms products will be derived in the next section. Since all the retail firms have access to the same technology, all the firms that are allowed to reset their prices will choose the same new price $\left(P_{t}^{*}\right)$ for their goods. We remember that the relative price $m_{t}$ is equal to $m_{t}=P_{t}^{m} / P_{t}$. Differentiation with respect to $P_{f, t}$ gives the first order condition for the price the retail firms will charge for their products:

$$
\frac{P_{t}^{*}}{P_{t}}=\frac{\epsilon}{\epsilon-1} \frac{E_{t} \sum_{s=0}^{\infty}(\beta \psi)^{s} \lambda_{t+s} P_{t+s}^{\epsilon} P_{t}^{-\epsilon} m_{t+s} y_{t+s}}{E_{t} \sum_{s=0}^{\infty}(\beta \psi)^{s} \lambda_{t+s} P_{t+s}^{\epsilon-1} P_{t}^{1-\epsilon} y_{t+s}}
$$

We define the relative price of the firms that are allowed to reset their prices to be equal to $\pi_{t}^{*}=P_{t}^{*} / P_{t}$, while gross inflation is defined to be equal to $\pi_{t}=P_{t} / P_{t-1}$. The above first order condition can now be rewritten in the following form:

$$
\begin{aligned}
\pi_{t}^{*} & =\frac{\epsilon}{\epsilon-1} \frac{\Xi_{1, t}}{\Xi_{2, t}} \\
\Xi_{1, t} & =\lambda_{t} m_{t} y_{t}+\beta \psi E_{t} \pi_{t+1}^{\epsilon} \Xi_{1, t+1} \\
\Xi_{2, t} & =\lambda_{t} y_{t}+\beta \psi E_{t} \pi_{t+1}^{\epsilon-1} \Xi_{2, t+1}
\end{aligned}
$$


The aggregate price level will be given by the following law of motion:

$$
(1-\psi)\left(\pi_{t}^{*}\right)^{1-\epsilon}+\psi \pi_{t}^{\epsilon-1}=1
$$

\subsubsection{Final Goods Producers}

The final goods firms purchase intermediate goods which have been repackaged by the retail firms in order to produce the final good. The technology that is applied in producing the final good is given by $y_{t}^{(\epsilon-1) / \epsilon}=\int_{0}^{1} y_{f, t}^{(\epsilon-1) / \epsilon} d f$, where $y_{f, t}$ is the output of the retail firm indexed by $f . \epsilon$ is the elasticity of substitution between the intermediate goods purchased from the different retail firms. We assume that the final goods firms operate in an environment of perfect competition, and hence they maximize profits by choosing $y_{f, t}$ such that $P_{t} y_{t}-\int_{0}^{1} P_{f, t} y_{f, t} d f$ is maximized. The final goods producer takes $P_{t}$ and $P_{f, t}$ as given. Taking the first order conditions with respect to $y_{f, t}$, gives the demand function of the final goods producers for the retail goods. Substitution of the demand function into the technology constraint gives the relation between the price level of the final goods and the price level of the individual retail firms:

$$
\begin{aligned}
y_{f, t} & =\left(P_{f, t} / P_{t}\right)^{-\epsilon} y_{t} \\
P_{t}^{1-\epsilon} & =\int_{0}^{1} P_{f, t}^{1-\epsilon} d f
\end{aligned}
$$

\subsubsection{Aggregation}

First we remember that $y_{f, t}=y_{i, t}=y_{t}\left(P_{f, t} / P_{t}\right)^{-\epsilon}$, for all $f$ and $i$. Hence we can write the factor demands by firm $i$ as:

$$
h_{i, t}=(1-\alpha) m_{t} y_{f, t} / w_{t}, \quad k_{i, t-1}=\alpha m_{t} y_{f, t} /\left[q_{t-1}^{k}\left(1+r_{t}^{k}\right)-q_{t}^{k}(1-\delta) \xi_{t}\right]
$$

Aggregation over all firms $i$ gives us aggregate labor and capital:

$$
h_{t}=(1-\alpha) m_{t} y_{t} \Delta_{t} / w_{t}, \quad k_{t-1}=\alpha m_{t} y_{t} \Delta_{t} /\left[q_{t-1}^{k}\left(1+r_{t}^{k}\right)-q_{t}^{k}(1-\delta) \xi_{t}\right]
$$

where $\Delta_{t}=\int_{0}^{1}\left(P_{f, t} / P_{t}\right)^{-\epsilon} d f$ denotes the price dispersion. It is given by the following recursive form:

$$
\Delta_{t}=(1-\psi)\left(\pi_{t}^{*}\right)^{-\epsilon}+\psi \pi_{t}^{\epsilon} \Delta_{t-1}
$$

Now we calculate the aggregate capital-labor ratio, and see that it is equal to the individual capitallabor ratio:

$$
k_{t-1} / h_{t}=\alpha(1-\alpha)^{-1} w_{t} /\left[q_{t-1}^{k}\left(1+r_{t}^{k}\right)-q_{t}^{k}(1-\delta) \xi_{t}\right]=k_{i, t-1} / h_{i, t}
$$

Now we calculate aggregate supply by aggregating $y_{i, t}=a_{t}\left(\xi_{t} k_{i, t-1}\right)^{\alpha} h_{i, t}^{1-\alpha}$ :

$$
\int_{0}^{1} a_{t}\left(\xi_{t} k_{i, t-1}\right)^{\alpha} h_{i, t}^{1-\alpha} d i=a_{t} \xi_{t}^{\alpha}\left(\frac{k_{t-1}}{h_{t}}\right)^{\alpha} \int_{0}^{1} h_{i, t} d i=a_{t}\left(\xi_{t} k_{t-1}\right)^{\alpha} h_{t}{ }^{1-\alpha}
$$

while aggregation over $y_{i, t}$ gives:

$$
\int_{0}^{1} y_{i, t} d f=y_{t} \int_{0}^{1}\left(P_{f, t} / P_{t}\right)^{-\epsilon} d f=y_{t} \Delta_{t}
$$


Hence we get the following relation for aggregate supply $y_{t}$ :

$$
y_{t} \Delta_{t}=a_{t}\left(\xi_{t} k_{t-1}\right)^{\alpha} h_{t}{ }^{1-\alpha}
$$

\subsection{Government}

For convenience we assume that the government levies lump sum taxes on the household and issues bonds to finance its expenditures. In the case of short term debt, the government uses the proceeds to repay the bonds that were issued in the previous period, and the (exogeneous) government expenditures. We assume that the government will default if the debt level is larger than a maximum level of debt to be defined below, like the debt limit in Davig et alii (2011) and Schabert and van Wijnbergen (2011). If this level is reached, the government will default on its debt. We describe the default process below. The government possibly also extends aid to the financial sector, when the quality of the capital, and hence the value of the associated financial assets, goes down after a negative capital quality shock, like in Gertler and Karadi (2011). We follow Kirchner and Van Wijnbergen (2012) in the way this policy is modeled:

$$
\begin{aligned}
n_{t}^{g} & =\tau_{t}^{n} n_{t-1}, \quad \zeta \leq 0, \quad l \geq 0 \\
\tau_{t}^{n} & =\zeta\left(\xi_{t-l}-\xi\right)
\end{aligned}
$$

Thus the government provides funds to the financial sector if $\zeta<0$, and a negative shock to the quality of capital occurs. Depending on the value of $l$, the government can provide support instantaneously $(l=0)$, or with a lag $(l>0)$. In addition, the government may or may not demand the financial sector to pay back the aid that was given. If it does the government receives a percentage of the funds provided earlier:

$$
\tilde{n}_{t}^{g}=\vartheta n_{t-e}^{g}, \quad \vartheta \geq 0, \quad e \geq 1
$$

The case where $\vartheta=0$ corresponds to the case where the net worth is a gift from the government to the financial intermediaries. In case $\vartheta=1$, the government aid can be viewed as a zero interest loan, while a $\vartheta>1$ implies that the financial intermediaries have to pay a penalty for the support received earlier ${ }^{2}$. The parameter $e$ denotes the amount of time after which the government aid has to be paid back. We assume that government purchases are constant, i.e. $g_{t}=G$. The government budget is now given by:

$$
b_{t}+\tau_{t}+\tilde{n}_{t}^{g}=g_{t}+n_{t}^{g}+\left(1-\Delta_{t}\right)\left(1+r_{t}^{b}\right) b_{t-1}
$$

where $\Delta_{t}$ is the default indicator in period $t$, which is $1(0)$ if the government does (not) default. We assume that the government follows a simple fiscal rule for its core tax policy $\tilde{\tau}_{t}$, as in Bohn (1998), which is given by:

$$
\tau_{t}=\bar{\tau}+\kappa_{b}\left(b_{t-1}-\bar{b}\right)+\kappa_{n} n_{t}^{g}, \quad \kappa_{b} \in(0,1], \quad \kappa_{n} \in[0,1]
$$

where $\bar{b}$ is the steady state levels of debt. Hence we see that the real public debt grows at a rate smaller than the gross real interest rate. This is in principle enough to guarantee government

\footnotetext{
${ }^{2}$ The case where $\vartheta>1$ happened in the Netherlands, where the big financial intermediaries were forced to accept government aid, which had to be paid back with a penalty rate of 50 percent on top of the loan.
} 
solvency, for a finite starting value of the public debt. Contrary to the case of no government default possibility, though, the level of debt influences the equilibrium allocation through the default process. If we set $\kappa_{n}=0$, the additional government transfers to the financial sector are completely financed by issuing new debt. By varying $\kappa_{n}$, we can investigate the effect of the way the government transfers are being financed. It is obvious that $\kappa_{n}=1$ implies that the additional spending is completely financed by increasing the lump sum taxes.

\section{Default process}

The fact that governments can default changes the expectations of investors. When this is not the case, the only condition to be satisfied is the requirement that the debt grows at a smaller rate than the nominal interest rate. In that case we have Ricardian equivalence, and an infinite number of government debt paths are possible. But when expectations of default influence debt prices, the path of government debt is not neutral anymore for the equilibrium allocation. We assume investors to have rational expectations. We assume that there is a maximum level of taxes that can be raised beyond which tax rates are not politically sustainable anymore, like in Schabert and Van Wijnbergen (2011). This translates in a maximum level of debt that can be sustained, a fiscal limit, and introduces the possibility of (partial) default if shocks trigger higher levels of debt than this fiscal limit. We follow Schabert and Van Wijnbergen (2011) in modelling default as a preemptive game between investors and the government, with the government following a mixed strategy, as in Benabou (1989) and Pastine (2002). This makes the maximum taxation level a random variable. We can map this maximum level of taxation into a maximum sustainable level of debt, which in turn is a random variable. We assume that this (random) fiscal limit is given by the following expression:

$$
b_{t}^{\max }=\bar{b}_{\text {max }}+\rho_{b}\left(b_{t-1}^{\max }-\bar{b}_{\max }\right)+\varepsilon_{b, t}
$$

Arellano (2008) endogenizes the default process, and similarly finds a random maximum debt level (which depends on shocks to the income process). The level of government debt to be issued if no default occurs $\left(\tilde{b}_{t}\right)$ is given by:

$$
\tilde{b}_{t}=g_{t}+n_{t}^{g}+\left(1+r_{t}^{b}\right) b_{t-1}-\tau_{t}-\tilde{n}_{t}^{g}
$$

If the amount of debt $\tilde{b}_{t}$ the government has to raise is larger than the maximum level of debt, the government defaults on its obligations rather than exceeding the fiscal limit in its effort to raise new debt. The taxes in the period of default will still be high, but in hte period after the default taxes will be lower, due to the lower level of debt. The government will have access to the debt market in the period of default because the maximum level of debt is a rndom variable, which makes default a random event too. If the amount of debt $\tilde{b}_{t}$ is lower than $b_{t}^{\max }$, the government does not default, and repays its creditors. The default indicator is now given by the following expression:

$$
\begin{array}{r}
\Delta_{t}=0 \text { if } \tilde{b}_{t} \leq b_{t}^{\max } \\
1 \text { if } \tilde{b}_{t}>b_{t}^{\max }
\end{array}
$$

In order to be able to solve the model, we approximate the default indicator by a normal cdf, with a very small variance. This way we capture the shape of the discontinuous variable by a continuous function. The default indicator is then given by:

$$
\Delta_{t}=\Phi\left(\tilde{b}_{t}-b_{t}^{\max } ; \mu=0, \sigma\right)
$$


where $\sigma$ determinses the curvature of the default function. If we stay close to the first inflection point of the CDF second order perturbation methods will suffice for a solution, but for larger shocks bringing us close to the second inflection point we will need higher order perturbation methods to capture the complete shape of the cdf.

\subsection{Central Bank}

We assume that the Central Bank sets the nominal interest rate on deposits $r_{t}^{n}$ according to a standard Taylor rule, in order to minimize output and inflation deviations:

$$
r_{t}^{n}=(1-\rho)\left(r^{n}+\kappa_{\pi}\left(\pi_{t}-\bar{\pi}\right)+\kappa_{y} \log \left(y_{t} / y_{t-1}\right)\right)+\rho r_{t-1}^{n}+\varepsilon_{r, t}
$$

where $\varepsilon_{r, t} \sim N\left(0, \sigma_{r}^{2}\right)$, and $\kappa_{\pi}>0$ and $\kappa_{y}>0$. The parameter $\bar{\pi}$ is the target inflation rate. We choose $\kappa_{\pi}>1, \kappa_{y}>0$, (leaning against the wind). The values of $\kappa_{\pi}$ and $\kappa_{y}$ determine the strength with which the authorities react to deviations from the natural or target rate of inflation and output. The nominal and the real interest rate on deposits are linked through the following Fisher relation:

$$
1+r_{t}^{d}=\left(1+r_{t-1}^{n}\right) / \pi_{t}
$$

Hence monetary policy is executed through the control of the interest rates on the deposits rather than the interest rates on the government bonds. The interest rate of the last category is endogeneously determined in equilibrium.

\subsection{Market clearing}

Equilibrium requires that the number of claims owned by the financial intermediaries $\left(s_{t}^{k}\right)$ must be equal to aggregate capital $\left(k_{t}\right)$, while the number of government bonds owned by the financial sector $\left(s_{t}^{b}\right)$ must be equal to the number of bonds issued by the government $\left(b_{t}\right)$ :

$$
\begin{aligned}
s_{t}^{k} & =k_{t} \\
s_{t}^{b} & =b_{t}
\end{aligned}
$$

Goods market clearing requires that the aggregate demand equals aggregate supply:

$$
c_{t}+i_{t}+g_{t}=y_{t}
$$

This completes the description of the model with short term debt only.

\section{Extension with perpetual bonds}

In this section we introduce an alternative schedule for government financing. Instead of bonds that are issued in period $t$, and repaid in period $t+1$, we now assume that the government issues perpetual bonds, or 'consols'. We assume that the government pays a flow of (interest) payments fixed in real terms $r_{b}$ indefinitely, until the consols are bought back by the government. Thus the consols represent a claim on an infinite stream of payments fixed in real terms. The consols are traded every period, and have a price $q_{t}^{b}$. The government can decide each period whether or not it will default on the consol payments in that period, which is again denoted by the default index variable $\Delta_{t}$. The introduction of consols changes the equations governing the financial sector as well as the government budget constraint. 


\subsection{Financial intermediaries}

The balance sheet of the typical financial intermediary is now given by:

$$
p_{j, t}=q_{t}^{k} s_{j, t}^{k}+q_{t}^{b} s_{j, t}^{b}
$$

An investor who purchases a consol in period $t$ for a price $q_{t}^{b}$, receives an interest payment $r_{b}$ in period $t+1$, and earns a return $r_{t+1}^{b}$ if he sells the consol in period $t+1$ for a price $q_{t+1}^{b}$ in case the government decides not to default:

$$
1+r_{t+1}^{b}=\frac{q_{t+1}^{b}+r_{b}}{q_{t}^{b}}
$$

This changes the equation for the net worth of individual intermediary $j$ in period $t+1$ :

$$
\begin{aligned}
n_{j, t+1} & =\left(1+r_{t+1}^{k}\right) q_{t}^{k} s_{j, t}^{k}+q_{t+1}^{b} s_{j, t}^{b}+\left(1-\Delta_{t+1}\right) r_{b} s_{j, t}^{b}-\left(1+r_{t+1}\right) d_{j, t}+n_{j, t+1}^{g}-\tilde{n}_{j, t+1}^{g} \\
& =\left(r_{t+1}^{k}-r_{t+1}^{d}\right) q_{t}^{k} s_{j, t}^{k}+\left(r_{t+1}^{b}-\frac{\Delta_{t+1} r_{b}}{q_{t} b}-r_{t+1}^{d}\right) q_{t}^{b} s_{j, t}^{b}+\left(1+r_{t+1}^{d}\right) n_{j, t}+\tau_{t+1}^{n} n_{j, t}-\tilde{\tau}_{t+1}^{n} n_{j, t}
\end{aligned}
$$

The leverage constraint is now given by:

$$
q_{t}^{k} s_{j, t}^{k}+q_{t}^{b} s_{j, t}^{b} \leq \phi_{t} n_{j, t}, \quad \phi_{t}=\frac{\eta_{t}}{\lambda-\nu_{t}^{k}}
$$

The first order conditions are given by:

$$
\begin{aligned}
\eta_{t} & =E_{t}\left[\Omega_{t+1}\left(1+r_{t+1}^{d}+\tau_{t+1}^{n}-\tilde{\tau}_{t+1}^{n}\right)\right] \\
\nu_{t}^{k} & =E_{t}\left[\Omega_{t+1}\left(r_{t+1}^{k}-r_{t+1}^{d}\right)\right] \\
\nu_{t}^{b} & =\nu_{t}^{k}=E_{t}\left[\Omega_{t+1}\left(r_{t+1}^{b}-\frac{\Delta_{t+1} r_{b}}{q_{t} b}-r_{t+1}^{d}\right)\right] \\
\Omega_{t+1} & =\beta \Lambda_{t, t+1}\left\{(1-\theta)+\theta\left[\eta_{t+1}+\nu_{t+1}^{k} \phi_{t+1}\right]\right\}
\end{aligned}
$$

While aggregate net worth evolves according to the following law of motion:

$$
\begin{aligned}
n_{t} & =\theta\left[\left(r_{t}^{k}-r_{t}^{d}\right) q_{t-1}^{k} s_{t-1}^{k}+\left(r_{t}^{b}-r_{t}^{d}\right) q_{t-1}^{b} s_{t-1}^{b}-\Delta_{t} r_{b} s_{t-1}^{b}+\left(1+r_{t}^{d}\right) n_{t-1}\right] \\
& +\chi p_{t-1}+n_{t}^{g}-\tilde{n}_{t}^{g}
\end{aligned}
$$

\subsection{Government budget}

First consider the budget constraint assuming the government does not default on its obligations. In that case, the government would need to issue an amount of debt equal to $q_{t}^{b} \tilde{b}_{t}$. This is given by the following expression:

$$
\begin{aligned}
q_{t}^{b}\left(\tilde{b}_{t}-b_{t-1}\right) & +\tau_{t}+\tilde{n}_{g, t}=g_{t}+n_{g, t}+r_{b} b_{t-1} \\
& \Rightarrow q_{t}^{b} \tilde{b}_{t}=g_{t}+n_{g, t}+\left(1+r_{t}^{b}\right) q_{t-1}^{b} b_{t-1}-\tau_{t}-\tilde{n}_{g, t}
\end{aligned}
$$

The maximum level of debt the government that the government before it will default on its debt is still given by:

$$
b_{t}^{\max }=\bar{b}^{\max }+\rho_{b}\left(b_{t-1}^{\max }-\bar{b}^{\max }\right)+\varepsilon_{b, t}
$$


Similar to the case of short term government debt, the government defaults on its obligations when the amount of no default debt $\tilde{b}_{t}$ the government has to raise is larger than this maximum level of debt. Hence the budget constraint is given by:

$$
q_{t}^{b}\left(b_{t}-b_{t-1}\right)+\tau_{t}+\tilde{n}_{g, t}=g_{t}+n_{g, t}+r_{b}\left(1-\Delta_{t}\right) b_{t-1}
$$

In order to be able to solve the model, we assume the default indicator is a continuous function, and approximate it by the cdf of a normal distribution with mean $\mu$ zero, and a very small variance:

$$
\Delta_{t}=\Phi\left(\tilde{b}_{t}-b_{t}^{\max } ; \mu=0, \sigma\right)
$$

where $\sigma$ determines the curvature of the default function.

\section{Results}

We first investigate the effect of a credit (capital quality) shock. We first introduce the case where the government is allowed to default on short term government debt, and compare it with the case without a default. Then we look at the impact of the same capital quality shock for the case where the government is financed through long term debt (consols). In both cases the government has the possibility to default on its debt. Finally, we analyse the impact of a recapitalization that is announced at the onset of the financial crisis, but implemented four quarters after announcement.

\subsection{Calibration}

The parameter values can be found in table 1. Most of the parameters are common in the literature on DSGE models, or frequently used in models containing financial frictions. We mostly follow the calibration of Gertler and Karadi (2011). This is the case for the subjective discount factor $\beta$, the degree of habit formation $v$, the Frisch elasticity of labor supply $\varphi^{-1}$, the elasticity of substitution among intermediate goods $\epsilon$, the price rigidity parameter $\psi$, the effective capital share $\alpha$, and the investment adjustment cost parameter $\gamma$. The calibration of the financial variables is also taken from Gertler and Karadi (2011). The steady state leverage ratio is set to 4, while the credit spread $\Gamma$ is set to 100 basis points annually (which amounts to $\Gamma=0.0025$ ), which coincides with the pre-2007 spreads in US financial data between BAA corporate and government bonds. The parameter $\theta$ is calibrated by taking the average survival period $(\Theta=1 /(1-\theta))$ to be equal to 36 quarters, or $\theta=0.9722$. The parameters in the Taylor rule are set to conventional values.

The feedback from government debt on taxes is set to a value such that both the model with and without default are stable. In order to match US macroeconomic data, we calibrate the steady state ratios of investment and government spending over GDP, $\bar{i} / \bar{y}$ and $\bar{g} / \bar{y}$ to 20 percent by calibrating the depreciation parameter $\delta$. The debt over GDP ratio $\bar{b} / \bar{y}$ is set equal to 2.4, implying an annual debt-to-GDP ratio of 60 percent. The steady state default probability is set to $\bar{\Delta}=0.02275$.

Even though government financing by financial intermediaries accounts for only a small part in the US, most financial friction models have been calibrated on US data. At first we follow the conventional calibration, leaving calibration on European data for the future. We assume more aggressive monetary policy in the face of a credit crisis, and hence set $\rho_{r}=0.4$ in times of crisis. We do not set it to zero, due to the fact that we might get below the zero bound. A credit crisis is represented by a negative shock to capital quality $\xi_{t}$ of 5 percent on impact, with an autocorrelation coefficient $\rho_{\xi}=0.66$, as in Gertler and Karadi (2011). 


\begin{tabular}{|c|c|c|}
\hline Parameter & Value & Definition \\
\hline \multicolumn{3}{|l|}{ Households } \\
\hline$\beta$ & 0.990 & Discount rate \\
\hline$v$ & 0.815 & Degree of habit formation \\
\hline$\Psi$ & 3.409 & Relative utility weight of labor \\
\hline$\varphi$ & 0.276 & Inverse Frisch elasticity of labor supply \\
\hline \multicolumn{3}{|c|}{ Financial Intermediaries } \\
\hline$\lambda$ & 0.3863 & Fraction of assets that can be diverted \\
\hline$\chi$ & 0.0021 & Proportional transfer to entering bankers \\
\hline$\theta$ & 0.9722 & Survival rate of the bankers \\
\hline \multicolumn{3}{|c|}{ Intermediate good firms } \\
\hline$\epsilon$ & 4.176 & Elasticity of substitution \\
\hline$\psi$ & 0.779 & Calvo probability of keeping prices fixed \\
\hline$\alpha$ & 0.330 & Effective capital share \\
\hline \multicolumn{3}{|c|}{ Capital good firms } \\
\hline$\gamma$ & 1.728 & Investment adjustment cost parameter \\
\hline$\delta$ & 0.0494 & Steady state depreciation rate \\
\hline \multicolumn{3}{|c|}{ Autoregressive components } \\
\hline$\rho_{z}$ & 0.95 & Autoregressive component of productivity \\
\hline$\rho_{\xi}$ & 0.66 & Autoregressive component of capital quality \\
\hline$\rho_{b}$ & 0.800 & Autoregressive component of maximum level of non default debt \\
\hline$\rho_{r}$ & 0.800 & Interest rate smoothing parameter \\
\hline \multicolumn{3}{|r|}{ 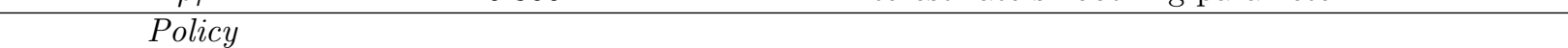 } \\
\hline$\kappa_{b}$ & 0.050 & Tax feedback parameter from government debt \\
\hline$\kappa_{\pi}$ & 1.500 & Inflation feedback on nominal interest rate \\
\hline$\kappa_{y}$ & 0.125 & Output feedback on nominal interest rate \\
\hline \multicolumn{3}{|c|}{$\frac{n y}{\text { Default parameters }}$} \\
\hline $\bar{\Delta}$ & 0.02275 & Steady state share of default indicator \\
\hline \multicolumn{3}{|r|}{ S } \\
\hline$\sigma_{z}$ & 0.010 & Standard deviation productivity shock \\
\hline$\sigma_{\xi}$ & 0.050 & Standard deviation capital quality shock \\
\hline$\sigma_{b}$ & 0.050 & Standard deviation maximum debt level shock \\
\hline$\sigma_{r}$ & 0.0025 & Standard deviation interest rate surprise shock \\
\hline
\end{tabular}

Table 1: Table with model parameters. 


\subsection{Default vs. No Default}

In this section we will investigate the effect of a credit quality shock when the government is financed through short term debt. We compare the case where the government is allowed to default, with the case where the government does not default, as in Kirchner and Van Wijnbergen (2012). We see from figures 1 and 2 that introducing the possibility of a government default does not have an effect on the economy, other than raising the expected interest rate on government bonds.
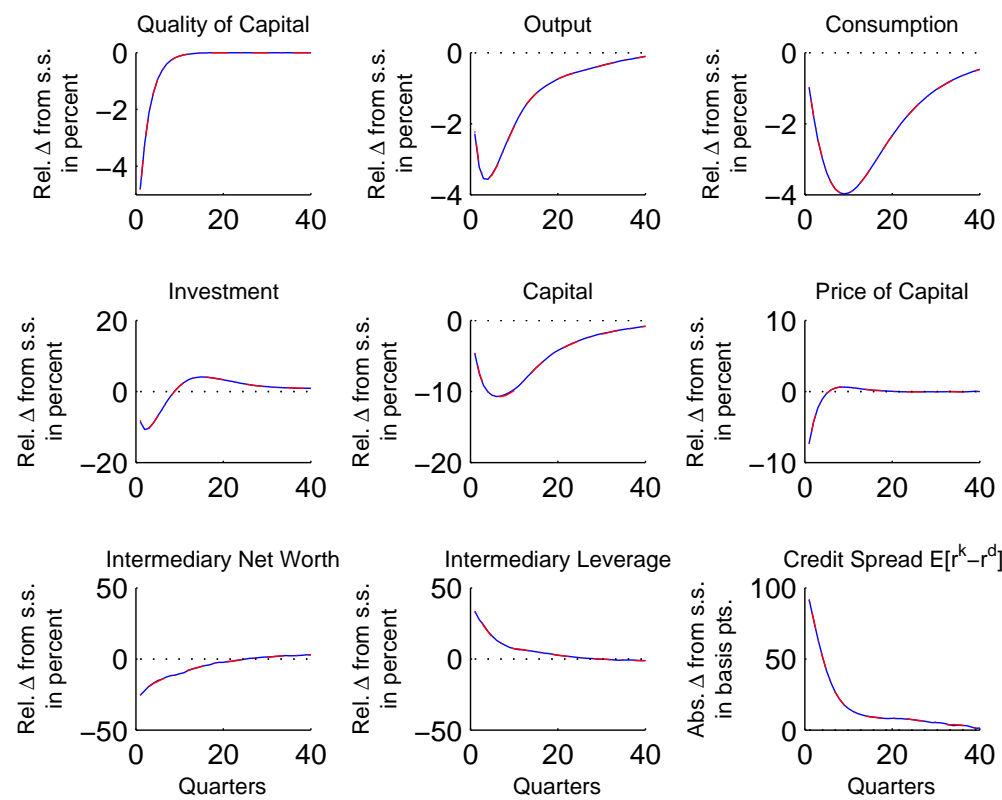

Figure 1: Plot of the impulse response functions for no default (blue) and default (red,-.-.) model after a negative capital quality shock of 5 percent relative to the steady state.

The underlying mechanism that drives the results is therefore the same as in Kirchner and Van Wijnbergen (2012). A decrease in the capital quality $\xi_{t}$ induces losses at the financial intermediaries on the loans provided to the intermediate goods producers. Due to these losses, the net worth of the financial intermediaries decreases, and hence the intermediaries become more balance sheet constrained, as can be seen from an increase in the credit spread by almost 100 basis points. The lower quality of capital also decreases the expected productivity from the capital that is purchased with the loans, and because of the lower net worth, the financial intermediaries decide to cut back on lending, which further reduces the price of capital, thereby raising the expected return on the loans. Due to arbitrage between private loans and government bonds, the expected interest rate on government bonds also increases, and makes it more expensive for the government to borrow. The decrease of the price of capital further deteriorates the losses on the private loans, which further reduce financial net worth, further reducing demand for capital. The intermediaries' balance sheet further deteriorates, further raising borrowing costs etc. Hence we see a pro-cyclical amplification 

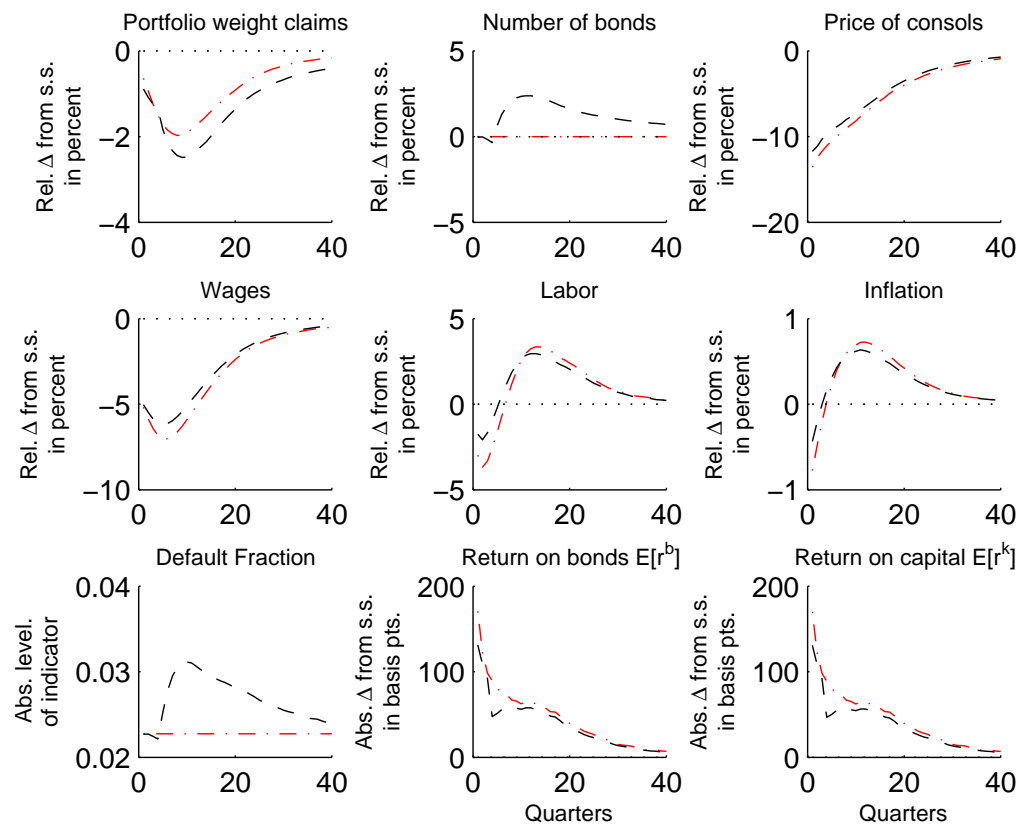

Figure 2: Plot of the impulse response functions for no default (blue) and default (red,-.-.) model after a negative capital quality shock of 5 percent relative to the steady state. 
cycle whereby investment and eventually capital drop by more than 10 percent.

A third balance sheet effect was highlighted by Kirchner and Van Wijnbergen (2012) and is due to crowding out by government debt. Government spending $g_{t}$ is fixed; then government borrowing is primarily affected by the interest rate $r_{t}^{b}$. Since the increase in the (expected) interest rates on private loans pushes up the (expected) interest rates on government debt, the absolute amount of government debt to be issued increases. Hence a smaller proportion of the intermediaries' balance sheets is available for financing the capital purchases of the intermediate goods producers. This effect is amplified because the size of the balance sheet is reduced as well, due to a tightening of the balance sheet constraint.

The lower capital quality reduces the "productivity" of the capital. Wages are lowered, and also due to reduced profits from the production sector and the financial intermediaries, the household's budget constraint is tightened, which reduces consumption. We see that output and consumption are reduced by more than 3 percent. We also see that after 40 quarters the economy has still not recovered completely from the initial shock. This model therefore implies that the effects of the most recent crisis might last for a decade.

Even though the interest rate on government debt increases very significantly, the possibility of a government default has no impact on the economy as long as debt is short term. The reason is the fact that due to rational expectations, investors anticipate that when the government has to increase borrowing, a larger fraction of government debt will be defaulted on. Investors anticipate this increase in the fraction of government debt (including interest payments on the bonds issued in the previous period) that the government will default on, and charge higher interest rates, thereby making sure that they will be paid out the same amount as in the no default case. Hence the investors, which are in this model the financial intermediaries, avoid capital losses on the government bonds purchased in the previous period. We will see that the situation is different in the case of perpetual bonds. New investors in government bonds will be less willing to purchase bonds when the probability of default increases, and hence offer a lower price, thereby restoring the expected return from the consols. But this drop in price will inflict a capital loss on holders of old consols.

\subsection{Short Term Government Debt vs. Consols}

But the introduction of long term debt and the associated possibility of capital losses does make a difference. Compare the impact of a capital quality shock under long term government bonds, or 'consols', with the case where government expenditures are financed through short term government debt. Figures 3 and 4 show the outcome in the two respective cases.

We see that the introduction of long term government debt with endogenous default risk has a major impact and significantly worsens the recession triggered by a negative quality of capital shock. The price of consols drops substantially, which leads to an additional deterioration of the intermediary sector's net worth, further tightening the balance sheet constraint. Due to the additional tightening of the balance sheet constraint, the credit spread doubles to 200 basis points, and the price of capital drops further, thereby doubling expected interest rates. These higher expected interest rates further reduce the demand for capital, thereby further lowering the demand for private sector loans. All these effects have significant effects on the real economy. The trough in output almost doubles, and a significant drop in investment further pushes down the capital stock. The reduction in capital lowers the demand for labor, and lowers wages and profits from the firms in the economy, which tightens the household budget constraint, further pushing down consumption. 

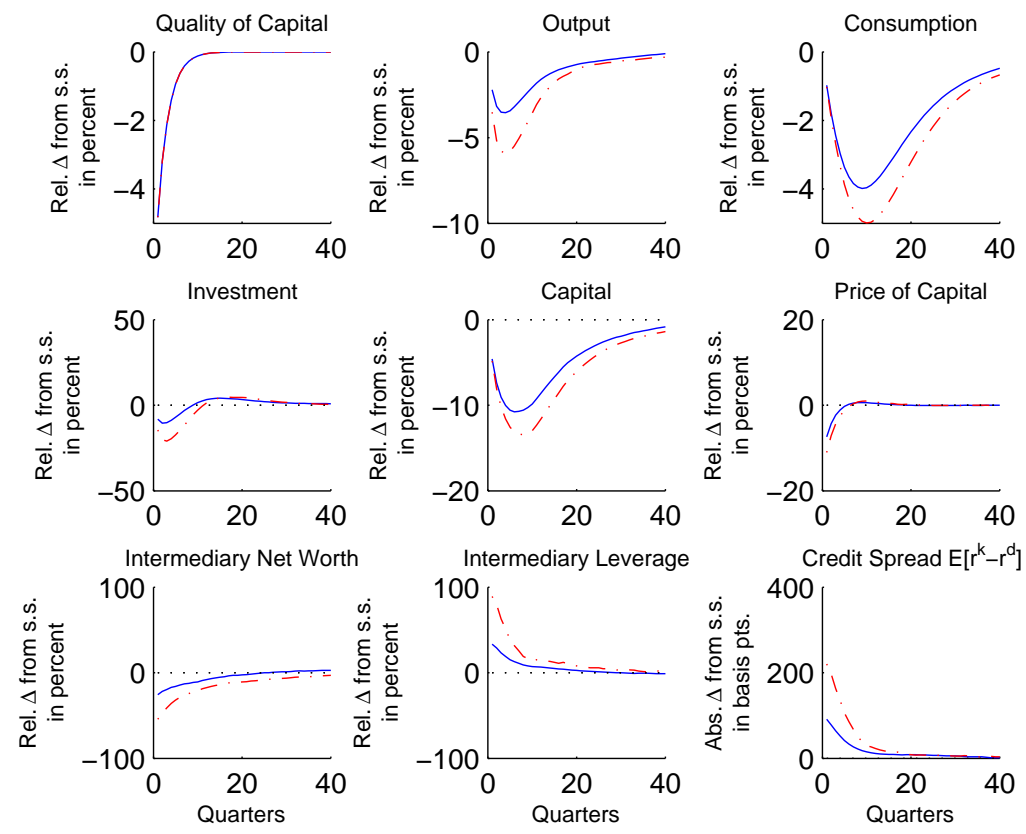

Figure 3: Plot of the impulse response functions for short term government debt (blue) and consols (red,-.-.) after a negative capital quality shock of 5 percent relative to the steady state. 

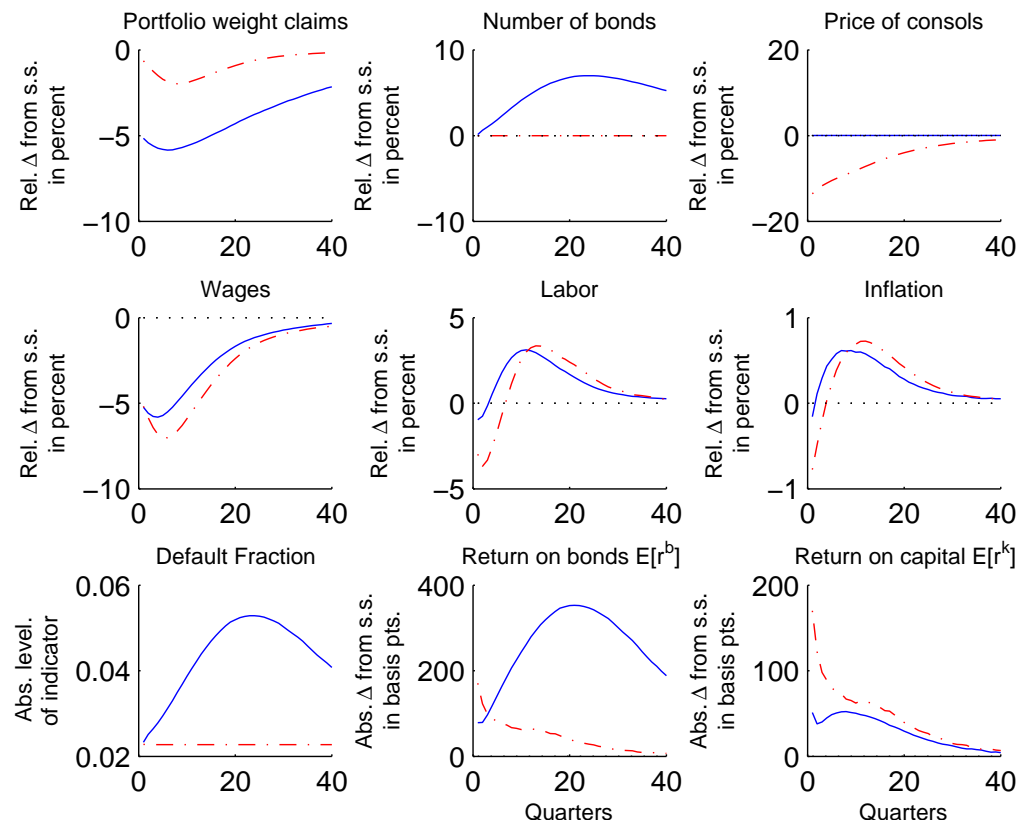

Figure 4: Plot of the impulse response functions for short term government debt (blue) and consols (red,-.-.) after a negative capital quality shock of 5 percent relative to the steady state. 


\subsection{No Policy vs. Pre-announced Recapitalization under Consols Fi- nancing}

In this section we evaluate a (delayed) recapitalization of the financial system by an issuance of new consols, which is announced at the start of the financial crisis, but implemented 4 quarters after the announcement. One would expect on the one hand financing conditions to improve due to the recap and associated increase in net worth, since the recap alleviates the balance sheet constraint. On the other hand the government has to issue more consols, which will cause the price of the consols to fall. The response of the economy can be found in figures 5 and 6 .
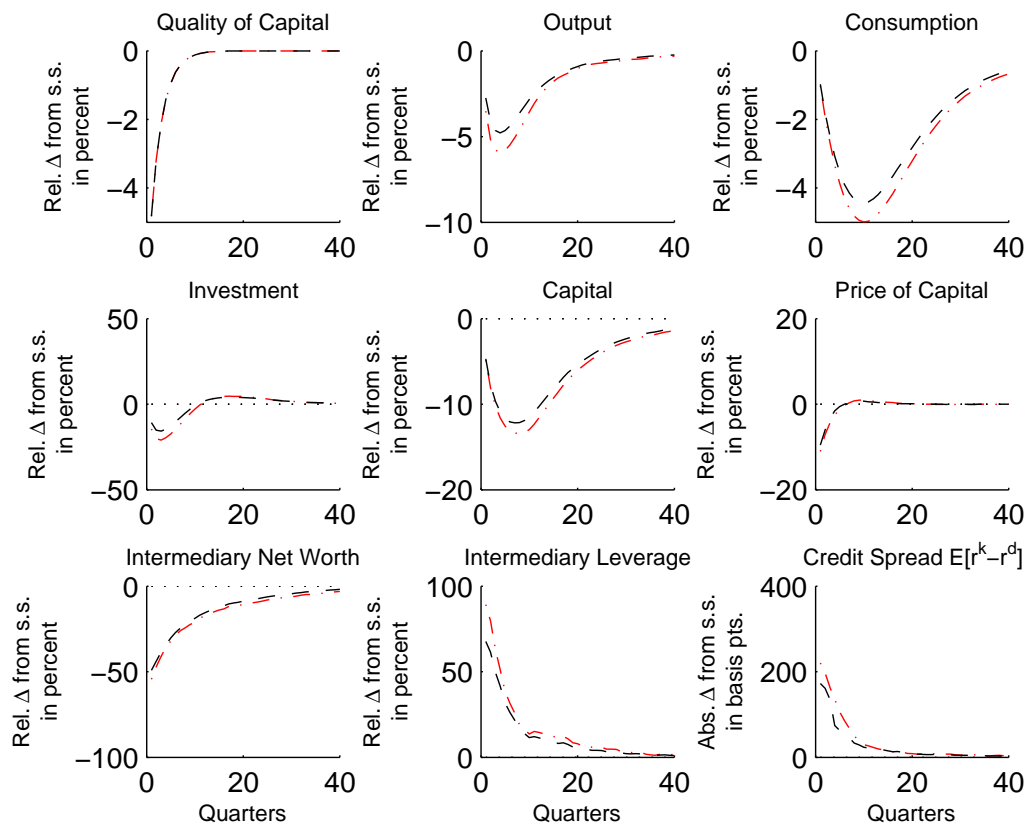

Figure 5: Plot of the impulse response functions for no intervention (red,-.-.) and delayed recapitalization (black,- - - -) of 5 percent of GDP after 4 quarters in case of an initial negative capital quality shock of 5 percent relative to the steady state.

We see that the announcement of the recapitalization has an immediate effect in itself, prior to the actual policy implementation: the financial intermediaries anticipate the recapitalization, which raises the continuation value of the financial intermediaries and so immediately relaxes the balance sheet constraint. Due to the relaxation of the balance sheet constraint, the demand for private loans and consols increases, driving up the price of these assets, thereby reducing the losses on the private loans (triggered by the initial capital shock). Net worth increases with respect to the no policy case, further reducing the losses of the financial intermediaries caused by the initial deterioration of the quality of capital, as well as reducing the credit spread by 50 basis points. When the actual recapitalization is implemented, a further drop in the credit spread of approximately 60 basis points occurs. Investment increases by almost 5 percentage points, due to a higher demand for capital. But 

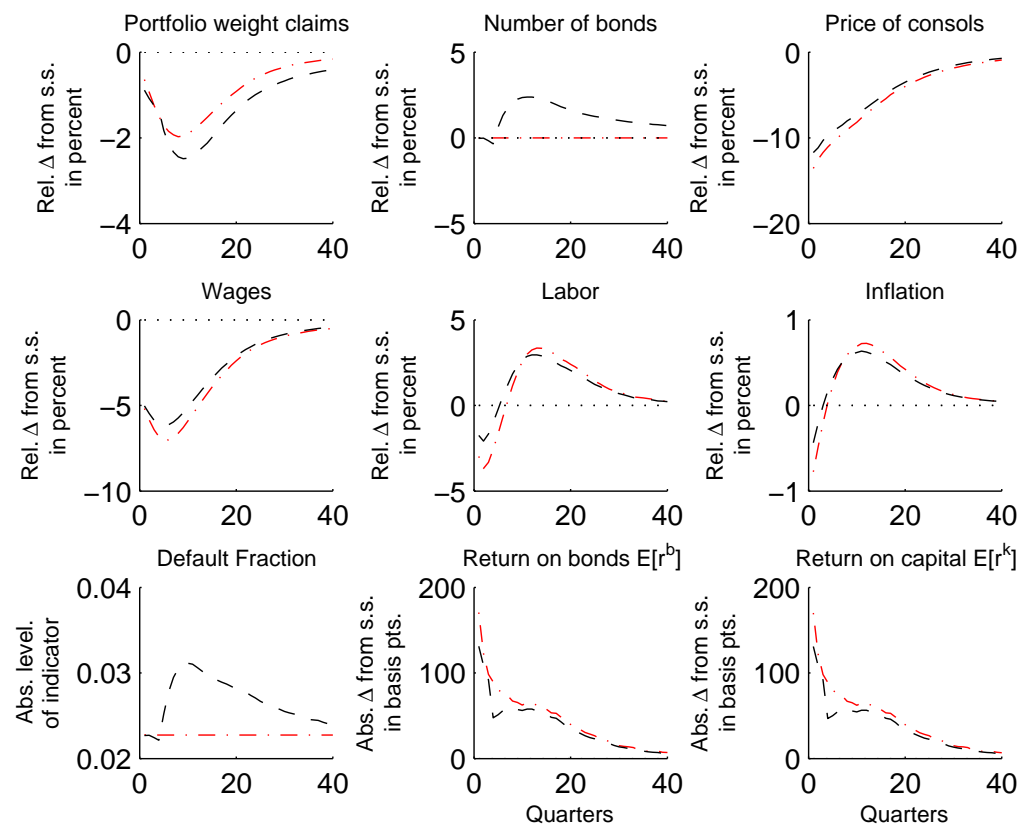

Figure 6: Plot of the impulse response functions for no intervention (red,-.-.) and delayed recapitalization (black,- - - -) of 5 percent of GDP after 4 quarters in case of an initial negative capital quality shock of 5 percent relative to the steady state. 
at the moment the recap is implemented, debt issue goes up and the default probability indicator increases sharply with associated impact on returns. The intervention, though, is preannounced, so intertemporal arbitrage makes sure that no further drop in the price of consols occurs at that moment, since everything is priced in at time zero, when debt prices go down. We see that the positive effects from a capital injection dominate the effects of increased sovereign default risk under the parameter values chosen.

\section{Conclusion}

In this paper we have investigated the effect of introducing sovereign default risk into a model containing financial intermediaries with public debt on their balance sheet and acting under a leverage constraint. We approximate the bimodal yes-or-no default process by a normal CDF with small variance indicating higher default percentages as debt levels exceed a trigger level related to a politically motivated maximum debt service capacity. We find that when the government uses short term government debt to finance its expenditures, the introduction of sovereign default risk does not have a significant impact on the economy because investors anticipate that the government will default on a larger fraction of government debt, and charge commensurately higher interest rates.

The situation is totally different when long term government debt, or 'consols' are introduced. Due to the fact that the cash flow from interest payments on "old" debt is fixed, existing bond holders incur a capital loss on their holdings of sovereign debt as the price of the consols drops. To the extent that financial intermeidaries hold sovereign debt among their assets, their leverage constraint tightens once capital losses occur, thus opening up a link between sovereign debt problems and financial fragility, through which sovereign debt problems have a negative impact on the corporate sector. We conclude that the maturity structure of government debt is a crucial element in the negative amplification cycle that can emerge from the interaction between balance sheet cosntraints of financial intermediaries and sovereign debt problems.

We show that this channel weakens the impact of debt financed recapitalization policies designed to alleviate balance sheet constraints in the financial intermediary sector, although more realistic calibration is needed to assess whether this amplification cycle is an important impediment to recovery from banking crises in heavily indebted countries. The main conclusion from this paper is the fact that the prevalence of long term government debt, while it may reduce roll over risk and associated public sector funding problems, also has negative macroeconomic consequences through the possibility of capital losses on sovereign debt holdings of financial intermediaries, an important feature of the European financial sector. 


\section{Bibliography}

Acharya, V.V., I. Drechsler, P. Schnabl (2011): "A Pyrrhic Victory?-Bank Bailouts and Sovereign credit Risk," NBER Working Paper, Working paper 17136

Arellano C. (2008): "Default Risk and Income Fluctuations in Emerging Economies," American Economic Review, Vol.98, No. 3, 690-712

Benabou, R. (1989): "Optimal Price Dynamics and Speculation with a Storable Good," Econometrica, $57,41-80$

Bernanke, B.S., M.L. Gertler, S. Gilchrist (1999): "The Financial Accelerator in a quantitative business cycle framework," Handbook of Macroeconomics, Volume 11999

Bohn, H. (1998): "The Behavior of U.S. Public Debt and Deficits," Quarterly Journal of Economics, 113, 949-963

Caballero, R.J. (2002): "Coping with Chile's External Vulnerability: A Financial Problem," Central Bank of Chile Working Papers, 2002-154

Calvo, G.A. (1983): "Staggered Prices in a Utility-Maximizing Framework," Journal of Monetary Economics

Christiano, L.J., M.S. Eichenbaum, and C.L. Evans (2005): "Nominal Rigidities, and the Dynamic Effects from a Shock to Monetary Policy," Journal of Political Economy, 113, 1-45

Davig T., E.M. Leeper, T.B. Walker (2011): "Inflation and the Fiscal Limit," European Economic Review, 55, 31-47

Gertler M.L., P. Karadi (2011): "A Model of Unconventional Monetary Policy," Journal of Monetary Economics, 58, 17-34

Gertler M.L., P. Karadi (2012): "A Framework for Analyzing Large Scale Asset Purchases as a Monetary Policy Tool," FRB conference paper in honor of Don Kohn, 58, 17-34

Gertler M.L., N. Kiyotaki (2010): "Financial Intermediation and Credit Policy in Business Cycle Analysis," in Handbook of Monetary Economics, vol. 3, 547-599. Elsevier

Homar T., S.J.G. van Wijnbergen (2013): "Recessions after Systemic Banking Crises: Does it Matter how Governments Intervene?", Tinbergen Institute Working Paper 13-039

Kirchner, M., S.J.G. van Wijnbergen (2012): "Fiscal Deficits, Financial Fragility, and the Effectiveness of Government Policies," Tinbergen Insitute WP 12-044/2

Kiyotaki N., J. Moore (1997): "Credit Cycles," in Journal of Political Economy. 
Lane, P.R. (2012): "The European Sovereign Debt Crisis," in Journal of Economic Perspectives, vol. 26, nr. 3, Summer 2012, 49-68

Pastine, I. (2002): "Speculation and the Decision to abandon a Fixed Exchange Rate Regime," Journal of International Economics, 57, 197-229

Schabert A., S.J.G. van Wijnbergen (2011): "Sovereign Default and the Stability of Inflation Targeting Regime," Discussion paper TI 2011-064/2/DSF 20

Uribe M. (2006): "A Fiscal Theory of Sovereign Risk," Journal of Monetary Economics, 53, 18571875

Yun, T. (1996): "Nominal Price Rigidity, Money Supply Endogeneity, and Business Cycles," Journal of Monetary Economics, 37, 345-370 